University of San Francisco

From the SelectedWorks of Tim Iglesias

2008

\title{
Our Pluralist Housing Ethics and Public-Private Partnerships for Affordable Housing
}

Tim Iglesias 


\title{
Chapter 3
}

\section{Our Pluralist Housing Ethics \& Public-Private Partnerships for Affordable Housing}

\author{
Tim Iglesias ${ }^{*}$
}

\author{
While affordable housing ${ }^{1}$ has been produced through a variety of public- \\ private partnerships (PPPs) for many decades, ${ }^{2}$ this fact is garnering new and \\ increasing attention by legal and policy analysts. ${ }^{3}$ This chapter considers how this
}

\footnotetext{
* Professor of Law, University of San Francisco School of Law. I am grateful to Robin Malloy and Nestor Davidson for organizing an intellectually stimulating and community-creating conference and for inviting me to attend. I also appreciated the many insightful comments I received from Nestor Davidson and other conference participants.

${ }^{1}$ In the chapter, "affordable housing" is defined as housing that is legally restricted for the use of persons or households who meet specific income requirements.
}

2 "Subsidized housing provides a fertile field of examination [of relational contracting] because policymakers, program managers, and private providers have been tinkering with the structures of privatization in that context for decades..." Nestor Davidson, Relational Contracts in the Privatization of Social Welfare: The Case of Housing, 24 YALE L. \& POL'Y REV. 263, 264 (2006) [hereinafter Davidson, Relational Contracts]. Examples of affordable housing developments often categorized as "PPPs" include: (1) developments in which government provided subsidies either directly (such as in HUD's programs Section 202 or Section 811) or indirectly (through the Low Income Housing Tax Credit program) to private housing developers (whether for-profit or non-profit); (2) developments in which local government provided regulatory relief (e.g., fee waivers) or regulatory incentives (e.g., density bonuses) to private housing developers; (3) developments in which local governments provided infrastructure, subsidy and/or land to private sector developers in redevelopment projects; (4) traditional public housing developments which are redeveloped by private developers through the HOPE VI program. See also U. S. Department of Housing and Urban Development (HUD), Guidebook: Building Public-private Partnerships to Develop Affordable Housing (Hud-1583-cpd, May 1996), available at http://www.ezrc.hud.gov/offices/cpd/ affordablehousing/library/modelguides/1583.cfm (last visited May 6, 2008).

\footnotetext{
${ }^{3}$ Examples of this, besides the conference itself, include: Angela M. Christy, Revitalizing PublicPrivate Partnerships (Chair's Message), 9 J. OF AFFORDABLE HOUSING AND COMMUNITY DEVElOPMENT LAW 207 (2007); Land Centre, The Role of Public-Private Partnerships in Producing Affordable Housing: Assessment of the U.S. Experience and Lessons for Canada, available at http://landcentre.dreamhosters.com/?q=node/4336 \& http://www.cmhc.ca/publications/en/rh-pr/socio/socio047.pdf (last visited May 6, 2008) (report examining how public-private partnerships (PPPs) have emerged in the United States as a delivery vehicle for the provision of affordable housing).
} 
new attention may affect the future of America's affordable housing movement ${ }^{4}$ through the lens of our pluralist housing ethics. ${ }^{5}$ After defining a "housing ethic," this chapter briefly explains our five housing ethics and reflects on our housing ethics pluralism. Then, after analyzing the PPP phenomenon using this framework, the chapter concludes that development of affordable housing through the form of PPPs presents important and even historic opportunities for affordable housing development but also substantial risks. ${ }^{6}$ Specifically, the proliferation of affordable housing PPPs could engender increased subsidies, continued experimentation with creative methods of developing affordable housing, improved public perceptions of affordable housing, and, most importantly, a fundamental repositioning of "affordable housing" in legal and policy debates. However, this phenomenon could also lead to the opposite outcomes. "Housing ethics" 7 are organizing principles (or paradigms) that have shaped the whole range of housing issues (from financing, production, and siting to the

\footnotetext{
${ }^{4}$ The chapter defines the affordable housing movement as non-profit affordable housing developers, the wide range of affordable housing advocates (e.g., community organizations, architects, etc.), and civil rights attorneys who work in the field.

5 The housing ethics framework was first explicated in Tim Iglesias, Our Pluralist Housing Ethics and the Struggle for Affordable Housing, 42 WAKE FOREST L. REV. 511 (2007) [hereinafter Iglesias, Pluralist Housing Ethics].

${ }^{6}$ Others, including Nestor Davidson, supra note 2 at 269 - 283, have discussed the challenges to efficiency and accountability posed by the development of affordable housing through publicprivate partnerships. This article focuses on the opportunities and risks to the broader affordable housing movement posed by PPPs.

7 The phrase "housing ethic" is modeled on Professor Fred Bosselman's use of the term "environmental ethic" in his article which spawned a significant literature on that topic, Fred Bosselman, Four Land Ethics: Order, Reform, Responsibility, Opportunity, 24 ENVTL. L. 1439 (1994). The conceptual object of this investigation could have been named otherwise. This chapter takes no position on the issue of whether the housing ethics function as rhetorical devices, framing devices, ideologies, or separate rationalities (with the potential for bounded rationality), or some combination of these. This issue is left to future scholarship.
} 
use of housing) at the federal, state, regional and local levels. More specifically, a "housing ethic" is an organizing principle that affects American housing law and policy by directing attention to certain kinds of facts and issues as relevant and important for policy and decision-making. It may be pre-reflective or consciously employed. It enables a certain kind of discourse with its own concepts and vocabulary. Beyond just categorizing the world, each ethic incorporates a normative dimension; it is poised toward decision and action in a value-laden way.

There are five distinct, decipherable and stable housing ethics deeply embedded in American housing policy and law that influence current housing law and policy through an on-going social dialogue. ${ }^{8}$ They are: (1) Housing as an Economic Good, (2) Housing as Home, (3) Housing as a Human Right, (4) Housing as Providing Social Order, and (5) Housing as One Land Use in a Functional System. ${ }^{9}$ Each housing ethic is now briefly explained. ${ }^{10}$

\footnotetext{
${ }^{8}$ This is an interpretative claim that places housing law and policy under one conceptual roof by identifying the deeper structures of American housing law and policy. Conference co-participant and keynote speaker Michael R. Diamond has addressed a related but distinct issue in J. Peter Byrne \& Michael R. Diamond, Affordable Housing, Land Tenure, and Urban Policy: The Matrix Revealed, 34 FORDHAM URB. L.J. 527, 528 (2007)(“This article attempts to organize and clarify the relationships among various goals of subsidized housing policy and the elements of programs adopted to meet them." ) [hereinafter Byrne and Diamond, Matrix Revealed].

9 "Housing as a focal point for self-governance" may be an additional emerging housing ethic. Currently, approximately fifty million Americans live in some form of "common interest community" ("CIC") in which housing ownership is linked to membership and voting rights in a self-governing body. CMTY. ASSN's INST., AN INTRODUCTION TO COMMUNITY ASSOCIATION LIVING 2-3, 35 (2003), available at http://www.regenesis.net/ community_association_living.pdf (last visited May 6, 2008). Some argue these developments enable community formation, social capital building, and citizenship skill building. Dell Champlin, The Privatization of Community: Implications for Urban Policy, 32 J. ECON. ISSUES 595 (1998) (discussing the economic and social reasons favoring CICs); Robert H. Nelson, Pro-Choice Living Arrangements, FORBES, June 14, 1999, at 222. Others argue that CICs are the latest form of exclusion and represent privatization of government. EDWARD J. BLAKELY \& MARY GaIl SNYDER, ForTRESS AMERICA: GATED COMMUNitiES IN THE United STATES 44 (1997). See generally Symposium, AALS Common Interest Communities Symposium, 37 URB. LAW. 325 (2005) (illustrating the various perspectives
} 
The Housing as an Economic Good ethic directs our attention to the fact that most housing is financed, produced and distributed by the private market. For many Americans, their house is their largest single investment and one of their largest monthly expenditures. Fortunes are regularly made and lost in the housing market. Therefore, this ethic focuses our attention on economic principles as critical to the formation of good housing law and policy. This familiar ethic is evidenced in real estate transactions law and a wide range of policies at all levels of government. From the perspective of this ethic, any proposed legal rule or policy affecting housing should be scrutinized on the basis of how this proposal will affect investment in housing development, applications for housing development permits, residential property values, and related economic consequences.

The Housing as Home ethic concentrates on the fact that homes are special spaces for the people who live in them. ${ }^{11}$ There they create their lives, their families, and their very selves. Therefore, this special space must be protected and expectations deriving from it should receive legal recognition. This ethic is expressed in a wide range of laws and policies generally benefiting current residents of housing. By and large, these laws and policies concern non-economic rights and privileges affecting safety, freedom and privacy, including the Fourth

on CICs). In the author's view, while these forms of housing are well-grounded in law, it is premature to determine whether or not they will create a new housing ethic.

${ }^{10}$ Interested readers will find much more extensive expositions of each housing ethic in Iglesias, Pluralist Housing Ethics, supra note 5, at 518 - 582.

${ }^{11}$ Another conference participant, Lorna Fox, has written extensively on this topic in the United Kingdom context, e.g., LORNA FOX, CONCEPTUALISING HOME: THEORIES, LAWS AND POLICIES (2007). 
Amendment of the United States Constitution. ${ }^{12}$ This ethic inquires of any proposed rule or policy: How will this proposal affect domestic privacy, security, household composition, and related values?

The Housing as a Human Right ethic contends that adequate, safe and affordable housing is critical to proper human development. Such housing enables individuals to be healthy, to take advantage of educational opportunities, to be productive members of the workforce, and to form nurturing families. Because housing is fundamental to proper human flourishing, this ethic urges that all people should have rights to housing protected by law. This ethic is expressed in the widespread adoption of the implied warranty of habitability as well as by more selective adoption of just cause eviction ordinances and rent control policies. And, it was addressed (although not embraced) in the important case Lindsey $v$. Normet. ${ }^{13}$ The question it asks of any new proposal is: How will this proposal affect access to and tenure in safe, decent housing?

The Housing as Providing Social Order ethic notes that the relative location of housing, types of housing and who lives in them-our housing settlement patterns — create a social order. Where and among whom we live structures important parts of our lives. Therefore, housing law and policy should respect and promote "good communities," including by respecting who people want to associate with in their neighborhoods. Evidence of this ethic's effects on our

\footnotetext{
12 Professor Ben Barros has summarized many of these laws and policies in D. Benjamin Barros, Home as a Legal Concept, 46 SANTA CLARA L. REV. 255 (2006).

${ }^{13}$ Lindsey v. Normet, 405 U.S. 56 (1972) (refusing to recognize an individual right to housing under the Due Process and Equal Protection Clauses of the Federal Constitution).
} 
housing law and policy include "Jim Crow" laws, racial and classist restrictive covenants, exclusionary zoning cases (e.g., the famous Mount Laurel cases) and the enactment of fair housing law. ${ }^{14}$ This ethic continually asks: How will this proposal affect who will live in "my community"?

The Housing as One Land Use in a Functional System ethic draws our attention to the fact that housing is only one of many land uses that are necessary for a healthy city. And, housing, like any land use, may have both positive and negative externalities. Therefore, housing law and policy should be conscious and deliberate about financing, producing, designing and siting housing, considering its relationships to other land uses in the relevant geographical unit. The marks of this ethic on our law and policy include comprehensive planning law, subdivision law, much of environmental law and numerous cases, e.g., Home Builders v. City of Napa. ${ }^{15}$ The primary concern of this ethic is: How will any housing law or policy affect infrastructure and schools, the jobs-housing balance and the environment?

The relationships among the five housing ethics are complex. The housing ethics are not consistently aligned with any particular interest group. Each ethic is not monolithic; there are several versions or strands of each ethic. For example, versions of the Housing as An Economic Good ethic vary depending upon each

\footnotetext{
${ }^{14}$ See, e.g., Douglas S. MASSEY \& NANCY A. DEnTON, AMERICAN APARTHEID (1993); James Kushner, Apartheid in America: An Historical and Legal Analysis of Contemporary Residential Segregation in the United States, 22 How. L.J. 547 (1979) (extensive analysis focusing on role of government and courts in causing segregation).

${ }^{15}$ Home Builders Ass'n of Northern California v. City of Napa, 108 Cal. Rptr. 2d 60 (Ct. App. 2001) (recognizing the functional importance and value of affordable housing for the city in upholding an inclusionary zoning ordinance against a facial regulatory takings claim).
} 
one's interpretations of housing markets and appropriate role for government policy towards them. ${ }^{16}$ Each ethic can support more than one social value, e.g., the Housing as One Land Use in a Functional System ethic can be concerned with efficiency, environmental quality and affordability. One or more of the five housing ethics often combine with each other in support of a particular legal rule or policy. A policy or law is most stable when supported by several housing ethics. ${ }^{17}$ The ethics also function as reciprocal constraints on each other. For example, effects on the cost of housing (Housing as An Economic Good ethic) are raised as a criticism to policies that would ensure habitability (Housing as a Human Right ethic).

The combination of the five housing ethics with these dynamics results in a "housing ethics pluralism" in which American housing law and policy supports numerous, diverse goals and interests but not in a consistent or coherent way. ${ }^{18}$

${ }^{16}$ See Iglesias, Housing Ethics, supra note 5, at $523-525$.

${ }^{17}$ For example, the promotion of homeownership—America's most enduring housing policy over the last 50 years-probably derives its stability from the fact that it can be supported by one version of all five of our housing ethics. The asset-building aspect of homeownership incorporates the "housing as economic good" ethic by focusing on a house as a good investment. Obviously, the economic interests of builders, realtors, and financial institutions also help explain the popularity of the policy. Homeownership appeals to the "housing as home" ethic by reassuring homeowners of their privacy rights and fueling imaginations about positive subjective meanings associated with "homes." There is a hint of the "housing as a human right" ethic in calls for government to regulate in such a way that makes the "American Dream" possible for all. Homeownership is consistent with the "housing as social order" ethic by its inference that: "You've really (only) made it in this society when you own your own home." The element of mobility that sometimes accompanies the American Dream presumes a hierarchically arranged set of neighborhoods in which one climbs from a good house in one neighborhood to a better house in a "better neighborhood." And, homeownership is consistent with the "housing as one land use of a functional system" ethic in the association of single-family houses in suburbs as good, safe places for raising children. The "American Dream" of homeownership is so powerful in part because it seamlessly weaves together versions of all of America's housing ethics.

\footnotetext{
${ }^{18}$ Any particular policy, legal rule or program can pit the ethics against each other; or certain versions of them can combine to support it; or proponents may try to use one ethic's power to support their policy which primarily serves another ethic. See, e.g., Megan J. Ballard, Legal
} 
Thus our housing ethics pluralism helps account for the past and current muddle of our housing law and policy. ${ }^{19}$

Coexistence among the housing ethics has been the norm historically in America, and is likely to persist. However, there is a potential for temporary or limited hegemony by one or more ethics. In the last few decades, two particular versions of housing ethics have been rising and arguably dominant: a deregulatory version of Housing as an Economic Good and a racial and classist exclusionary version of the Housing as Providing Social Order ethic.

The deregulatory version of Housing as an Economic Good is founded on the view that our housing affordability problem is caused by the cumulative effect of government regulations raising the production costs of housing. The proposed solution is to deregulate. On this view, government subsidies for housing become unnecessary if government lets the markets work. ${ }^{20}$ The racial and classist

Protections for Home Dwellers: Caulking the Cracks to Preserve Occupancy, 56 SYRACUSE L. REV. 277, 277 (2006) (employing "housing as home ethic" arguments to promote adoption of new housing rights for tenants).

${ }^{19}$ Numerous publications describe this muddle. See, e.g, R. A. Hays, Housing America's poor: Conflicting values and failed policies, 28 J. OF URBAN HISTORY 369-381 (2002); Rachel G. Bratt, Nonprofit Developers and Managers: The Evolution of their Role in U.S. Housing Policy, in SHELTER AND SOCIETY: THEORY, RESEARCH, AND POLICY FOR NONPROFIT Housing (C. Theodore Koebel ed., 1998); Bishwapriya Sanyal, Beyond the Theory of Competitive Advantage: Political Imperatives of the Government-Nonprofit Relationship, in SHELTER AND SOCIETY: THEORY, RESEARCH, AND POLICY FOR NONPROFIT Housing (C. Theodore Koebel ed., 1998). Professors Bryne's and Diamond's article implicitly explain the muddle as either the result of policymakers naively ignoring inherent tradeoffs, or as a failure to achieve a more comprehensive policy that deliberately and rationally takes the tradeoffs into account. Byrne and Diamond, Matrix Revealed, supra note 8, at 528 - 530, 611. In contrast, in the author's view, the confusion and unclarity of our housing policy is largely due to the dynamics of our housing ethics pluralism.

${ }^{20}$ Note that in contrast to this view, even the National Association Home Builders supports government housing subsidies including the federal mortgage interest deduction and other types of subsidies under some circumstances. See, e.g., National Association of Home Builders, Government Support for Affordable Housing, available at http:// www.nahb.org/generic.aspx?genericContentID=79486 (last visited April 19, 2008). 
exclusionary version of the Housing as Providing Social Order ethic is regularly expressed in continued exclusionary zoning and Not-In-My-Back-Yard opposition to proposed affordable housing development. ${ }^{21}$ These two particular versions of housing ethics are in profound conflict with the stability and flourishing of the affordable housing movement.

In response, the affordable housing movement has articulated different versions of each of these ethics, analyzing our chronic housing crisis as an effect of various market failures justifying governmental regulation, ${ }^{22}$ and promoting an “inclusionary” Housing as Providing Social Order ethic through laws and policies (such as federal fair housing law) designed to integrate neighborhoods and cities. $^{23}$

Due to our persistent housing ethics pluralism, America is not likely to ever have a completely coherent, efficient and equitable housing production policy. ${ }^{24}$ Therefore, the affordable housing movement needs to survive our housing ethics pluralism by successfully resisting the attempted hegemony of a deregulatory

\footnotetext{
${ }^{21}$ While facially discriminatory housing policies are now illegal, substantial racial/ethnic housing discrimination still exists. These laws and policies have left a legacy of widely recognized class and race segregated neighborhoods and communities. It is hard to underestimate the influence of these past laws and policies on current attempts to promote affordable housing that would have the effect of increasing racial and class integration. In addition, ongoing legal and public acceptance of class-based housing patterns poses a formidable challenge to affordable housing development.

${ }^{22}$ See, e.g., National Housing Institute, Our Housing Markets Don't Work, SHELTERForCE MAGAZINE, May/Jun 2001. See Byrne and Diamond, Matrix Revealed, supra note 8, at 530 - 531 ("...[I]t is widely accepted that the market will not provide housing that meets community standards.”)

${ }^{23}$ In addition, the housing movement has begun to rely more on the Housing as One Land Use in a Functional System ethic and less on the Housing as a Human Right ethic. See discussion infra at notes $62-69$ and accompanying text.

${ }^{24}$ This conclusion appears to conflict with the implicit hope of such a policy evinced by Professors Byrne and Diamond in Matrix Revealed, supra note 8.
} 
version of Housing as an Economic Good and a racial and classist exclusionary version of the Housing as Providing Social Order ethic. It also needs to adapt so as to thrive in our housing ethics pluralism, for example by expanding its appeal to a version of each of the ethics. As explained below, affordable housing development by PPPs offers opportunities for both surviving and thriving in our housing ethics pluralism, but also presents risks for the affordable housing movement.

Gauging the prospects of PPP development for affordable housing using the housing ethics framework, it is important to define PPP in affordable housing development. PPP is an ambiguous, value-laden and potentially ideological term. There is now a vast literature debating the meaning of "public-private partnerships" and discussing their benefits and costs. ${ }^{25}$ For some, "PPP" is only a marketing label pragmatically employed to promote a particular housing development deal. Consequently, for these the term "PPP" has no real consistent substance. Others embrace a narrow economic view, assuming housing is only a private economic good and assuming the market is always the best provider. On this view, PPP is merely one form of "privatization," a one-way movement transferring traditional governmental duties or operations to the private market. ${ }^{26}$

\footnotetext{
25 See, e.g., Stephen H. Linder, Coming to Terms With the Public-Private Partnership: A Grammar of Multiple Meanings, AMERICAN BEHAVIORAL SCIENTIST 35-51 (1999); Nick Beerman, Comment: Legal Mechanisms of Public-Private Partnerships: Promoting Economic Development or Benefiting Corporate Welfare, 23 SEATTLE U. L. REV. 175 (1999); Angela M. Christy, Revitalizing Public-Private Partnerships (Chair's Message), 9 J. OF AFFORDABLE Housing AND COMMUNITY DEVELOPMENT LAW 207 (Spring 2007).

26 The sale of public housing units to tenants without any future affordability requirements is an example of such uni-directional privatization. See, e.g., Robert Pear, Panel Urges Sale of Public Housing, NEW YORK TIMES, November 11, 1987, available at
} 
This view reduces the scope of PPP options to the types of subsidy that government might provide for-profit housing producers.

Broader definitions of PPPs open up a wide variety of options. For purposes of this chapter, I adopt a broad functional definition of a PPP (drawn largely from Marc Mihaly $^{27}$ as a cross-sectoral ${ }^{28}$ collaboration involving shared allocation of resources, risk, ${ }^{29}$ and/or other activities/roles and responsibilities usually based upon relative skills, competencies or other circumstances ${ }^{30}$ to achieve a combination of public and private goals. ${ }^{31}$

http://query.nytimes.com/gst/fullpage.html?res=9B0DE6D81F3DF932A25752C1 A961948260 (last visited May 5, 2008).

${ }^{27}$ Marc B. Mihaly, Public-Private Redevelopment Partnerships and the Supreme Court: Kelo v. City of New London, 7 VT. J. ENVTL. L. 41 (2005/2006) [hereinafter Mihaly, Public-Private Redevelopment Partnerships].

${ }^{28}$ I include any combination of the following three sectors: governments, the market, or civil society (including religious organizations and non-profits).

${ }^{29}$ The types of risk that can be allocated among the parties include: (1) market risk (the risk that rental and sales markets will change); (2) development risk (the risk of losing money, e.g., sunk costs in predevelopment costs); (3) regulatory risk (the risk that the project will not get its needed discretionary land use approvals); and (4) construction risk (that cost overruns will be high). Mihaly, Public-Private Redevelopment Partnerships, supra note 27, at $59-60$.

${ }^{30}$ Mihaly, Public-Private Redevelopment Partnerships, supra note 27, at $51-52,58$.

${ }^{31}$ Each of the PPPs listed supra in note 3 could be understood within this definition. These collaborations are usually memorialized in legally-enforceable agreements. My definition is an example of what Professor Davidson terms "the pragmatic approach." Davidson, Relational Contracts, supra note 2, at 269. A similar definition appears in SHELTER AND SOCIETY: THEORY, RESEARCH, AND POLICY FOR NONPROFIT Housing (C. Theodore Koebel ed., 1998). The chapter entitled Public-Private Partnerships for Affordable Housing: Definitions and Applications in an International Perspective offers several definitions of PPPs including "full partnerships" as a form of inter-sectoral cooperation distinguished by "shared responsibilities, joint decision-making and mutual commitment of resources." Id. at 42. Similarly, the ENCYCLOPEDIA OF HOUSING entry for "Public/Private Housing Partnership" defines a PPP as a partnership "in which private persons or entities carry out specific programs or projects in conjunction with public agencies, sharing control and using both private and public resources." THE ENCYCLOPEDIA OF HOUSING 448-9 (Willem Van Vliet ed., 1998). The Encyclopedia defines a "partnership" as "a voluntary association of two or more persons or entities who agree to carry out a business together, with mutual participation in profits and benefits." Ibid. 
The primary opportunities that the PPP development of affordable housing offers to the affordable housing movement are: (1) increasing subsidies; (2) expanding the scope of experimentation with methods of developing affordable housing; (3) changing public perceptions of affordable housing; and (4) repositioning affordable housing in legal and policy debates.

Developing affordable housing under the rubric of PPPs might increase the amounts of subsidies available from government and also private parties. ${ }^{32}$ Elected officials who have been skeptical of government production of affordable housing, and particularly those who focus on the limited but widely-publicized failures of the public housing program, may lend more support to affordable housing development if financing, production and/or management were performed jointly by the public and private sectors. This view may help explain the enactment and continuing vitality of the federal LIHTC program that currently provides the largest federal subsidy for affordable housing development. ${ }^{33}$

$32 \ldots[\mathrm{I}] \mathrm{n}$ a time of diminishing federal and other governmental resources, we need to rely on the market and other forces for larger scale answers. Inclusionary zoning in strong markets, tax increment financing, larger foundations using the financial power of their endowments for social purposes and tapping into individual and family foundations that will see an exponential transfer of wealth over the next 10 years. In short, we need to stabilize the public part of the public/private partnership and greatly expand the private part until this country has the will to properly address its human needs.

Bart Harvey, Building Alliances at All Levels, 144 SHELTERFORCE MAGAZINE, November/December 2005, available at http://www.nhi.org/online/issues/144/buildingalliances.html (last visited January 12, 2008).

33 Under the LITHC program, private investors exchange equity investments in affordable housing developments for federal income tax credits. For a brief explanation of how the LIHTC program works, see Adam McNeely, Improving Low Income Housing: Eliminating the Conflict Between Property Taxes and the LIHTC Program, 15 J. AFFORDABLE HOUSING \& COMMUNITY DEV. L. 324, 325 - 329 (2006). "Whether from a syndicator or directly from the developer, corporations purchase about 70 percent of the tax credits awarded nationwide through the LIHTC." Citing Eric A. Smith, Low-Income Housing Tax Credit Basics, 3 J. FIN. PlAN. 114, 116 (2000). 
Successful PPP models such as the Vermont Housing and Conservation Board, ${ }^{34}$ the Georgia Quality Growth Partnership, ${ }^{35}$ and Neighborhood Assistance Programs ${ }^{36}$ may be replicated more broadly. In the wake of federal withdrawal since the early 1980's, state and local governments have significantly increased their involvement in affordable housing development, including by providing resources and by joining in various PPPs. ${ }^{37}$ The need for "workforce housing"-affordable housing for teachers, nurses, municipal workers (such as police officers and firefighters) and other workers--has attracted the attention of chambers of commerce, employers (e.g., the Silicon Valley Manufacturing Group) and others.

\footnotetext{
34 "The Vermont Housing and Conservation Board is an independent, state-supported funding agency providing grants, loans and technical assistance to nonprofit organizations, municipalities and state agencies for the development of perpetually affordable housing and for the conservation of important agricultural land, recreational land, natural areas and historic properties in Vermont." For more information, visit Vermont Housing \& Conservation Board, http://www.vhcb.org/ (last visited January 12, 2008). "To anyone concerned with both affordable housing and open space, the 12-year-old Vermont Housing and Conservation Trust Fund is seen as a model." Miriam AxelLute, A Meeting of Movements, 103 SHELTERFORCE MAGAZINE, January/February 1999.
}

${ }^{35}$ Founded in March, 2000, The Georgia Quality Growth Partnership (GQGP) has grown to more than thirty organizations. These partners each contribute time, in kind services, or financial resources to foster Partnership efforts. GQGP Toolkit, http://www.dca.state.ga.us/toolkit/toolkit.asp (last visited April 19, 2008).

36 "Now in use by 11 states - Connecticut, Delaware, Florida, Indiana, Kansas, Maryland, Missouri, Nebraska, Pennsylvania, Virginia, and West Virginia - with legislation pending in at least two others, neighborhood assistance programs (NAPs) provide tax credits to businesses that contribute (cash, materials, staff) to community-based non-profit organizations, often targeting low-income people and communities" including for affordable housing development. Carol Wayman, Neighborhood Assistance Programs, SHELTERFORCE MAGAZINE, January/February 1997.

37 In SHELTER BuRden, Professor Ed Goetz of the University of Minnesota focuses on the local government response to federal cutbacks in housing in the 1980-1990 decade. During this period, he estimates that increased state and local governmental spending on low- and moderate-income housing made up approximately one-third of the loss of federal aid.

W. Dennis Keating, The Housing Affordability Crisis: Progressive Responses, Book Review: Edward G. Goetz, SHELter BuRden: Local Politics AND Progressive Housing Policy (Temple University Press 1993), SHELTERFORCE MAGAZINE, March/April, 1994, available at http://www.nhi.org/online/issues/books/74.html (last visited January 12, 2008). PPPs was one of the four models of local low-income housing delivery systems that Professor Goetz analyzed. 
Wealthy private individuals, corporations or foundations may offer more

resources for affordable housing development in PPP funding mechanisms such as The Housing Trust of Santa Clara County. ${ }^{38}$

The promotion of affordable housing development as PPPs will enable and encourage affordable housing providers to continue experimenting creatively with various versions of PPPs. As the majority in the Kelo case recognized, PPPs can create "a whole greater than the sum of its parts." 39 There is still much to be explored in the fractionalization of property rights and in combining the various roles and responsibilities of private and public partners towards different private and public goals. ${ }^{40}$ For example, municipalities are now partnering with nonprofit developers in establishing "community housing trusts," a strategy previously implemented by non-profits alone. ${ }^{41}$ In this regard, an important

\footnotetext{
38 "The Housing Trust of Santa Clara County is a catalyst to develop specific, desperately needed housing in Santa Clara County through an innovative blend of corporate and community investors." For more information, visit The Housing Trust of Santa Clara County, http://www.housingtrustscc.org/ (last visited January 12, 2008). Public-Private Partnership Announces Loan Fund to Create Affordable Housing in Louisiana, PHILANTHROPY NEWS DIGEST, April 26, 2007, available at http://foundationcenter.org/pnd/news/story.jhtml?id=176500022 (last visited January 12, 2008). San Francisco Mayor Gavin Newsom toured public housing with very wealthy individuals to solicit money for rehabilitation. Heather Knight, Newson Taking Rich on Tours of Housing for Poor: He Seeks Donations to Rebuild Projects, SAN FRANCISCO CHRONICLE, August 29, 2007, at A1. For an example of a successful cross-sectoral partnership between the for profit and non-profit sectors, see Scott Anderson, Building Partnerships for a Better Tomorrow, 3(5) The CAmpaign For AfFordable Housing Newsletter (The Campaign for Affordable Housing, Los Angeles, CA), September 10, 2007, at 3 (describing Habitat for Humanity's longstanding partnership with the Whirlpool corporation).

${ }^{39}$ Kelo v. City of New London, Conn. et al., 125 S. Ct. 2655, 2665 (2005). Other commentators understand housing PPPs in a similar way. See, e.g., Richard Steinberg, The Theory of the Nonprofit Sector in Housing, in SHELTER AND SOCIETY: THEORY, RESEARCH, AND POLICY FOR NONPROFIT Housing 35 (C. Theodore Koebel ed., 1998) ("Housing partnerships may create synergistic benefits and costs, providing a whole different from its parts.").

${ }^{40}$ For a taste of this discussion see Mihaly, Public-Private Redevelopment Partnerships, supra note 27; Davidson, Relational Contracts, supra note 2. 
unresolved question is: Are PPPs with non-profits in housing substantially distinct and better at achieving some public purposes than PPPs with for-profit actors? ${ }^{42}$ If so, this could lead to expansion of the Third Sector in which consumer housing prices are not subject to market forces. ${ }^{43}$

It is no secret that affordable housing has a huge public relations problem. This difficulty is often discussed under the rubric of "exclusionary zoning" and/or the Not-In-My-Back-Yard ("NIMBY") phenomenon. ${ }^{44}$ One intriguing opportunity of greater public recognition of affordable housing development as a

community land trust (CLT) is increasingly being adopted by local governments facing urgent housing-affordability needs. ... [M] unicipalities as different as Irvine, Calif., Chicago, Ill., Sarasota County, Fla., Austin, Texas, Delray Beach, Fla., Highland Park, Ill., Las Vegas, Nev., and Chaska, Minn., have taken the lead in creating their own CLTs. This trend represents an important evolution of the CLT model and a significant rethinking of the goals and roles of municipal government in promoting and preserving affordable housing.

Rick Jacobus \& Michael Brown, City Hall Steps In, 149 SHELTERForCE MAGAZINE, Spring 2007, available at http://www.nhi.org/online/issues/149/cityhall.html (last visited May 6, 2008).

${ }^{42}$ See Rocky Tarantello, Affordable Housing Through Non-Profit/Private-Public Partnerships, BUSINESS NETWORK, Fall 1998, available at http://findarticles.com/p/articles/mi_qa3681/is_199810/ai_n8823514 (arguing non-profits and local governments are "natural partners").

43 See SHElter AND SOCIETY: THEORY, RESEARCH, AND POLICY FOR NONPROFIT HOUSING (C. Theodore Koebel ed., 1998); THE AfFordABLE CITY: TOWARD A THIRD SECTOR Housing POLICY (John Emmeus Davis ed., 1994); Property AND VAlues: Alternatives TO PUBLIC AND PrIVATE OWNERSHIP (Charles Geisler \& Gail Daneker eds., 2000) (Chapters $10-12$ focus on housing).

44 Right now, the face of public housing is the face of people on the dole who have no legitimate rights to that assistance. That's not true. That doesn't describe public housing, so it's a big job of education. The face of housing assistance programs is that it's a porkbarrel that feeds rich developers. The fact is that many programs that involve publicprivate partnerships are quite effective in delivering good products, but the public image is it is just a big scam for rip-off artists. We have to educate the public as to what's been going on."

Interview by Chester Hartman with Bill Apgar, Executive Director, Harvard's Joint Center for Housing Studies, in ShElTERFORCE MAGAZINE, July/August 1995 (William C. Apgar, Jr. is Executive Director of Harvard's Joint Center for Housing Studies.) See also Tim Iglesias, Managing Local Opposition to Affordable Housing: A New Approach to NIMBY, 12 J. OF AFFordable Housing \& COMMUNITY DEVElopment LAW 78, 79 - 83 (2002) (discussing exclusionary zoning and NIMBY). Note that the relatively recent change from using the terms "low-income housing" or "low-cost housing" to using the term "affordable housing" has its roots in a recognition of this problem. 
PPP is whether it can be used to change negative public perceptions of affordable housing.

Affordable housing has strong historical and actual links to poverty and "race." $" 45$ Lately, however, the media and many policymakers have been recognizing that our chronic affordable housing crisis actually affects a wide range of working families with "good jobs." 46 Yet, deeply-engrained images of public housing failures combined with unsympathetic stereotypes of the expected occupants obstruct the adoption of more favorable policies. These perceptions hinder the affordable housing movement's attempt to get more subsidies, to improve local siting policies, and to deal with local opposition to proposed affordable housing developments. These perceptions and attitudes are hard to replace. ${ }^{47}$ Yet more (and more positive) public attention may be drawn to affordable housing constructed under a PPP arrangement because the private sector partners may have an interest in gaining public attention for their roles. And, they may have more expertise in attracting and sustaining public attention

\footnotetext{
${ }^{45}$ This chapter uses the term "race" recognizing that it is a social construct. See Ian F. Haney Lopez, The Social Construction of Race: Some Observations on Illusion, Fabrication and Choice, 29 HARV. C.R.-C.L. L. REV. 1 (1994).

${ }^{46}$ Joint Center for Housing Studies of Harvard University \& Center for Workforce Preparation of the U.S. Chamber of Commerce, Strengthening our Workforce and our Communities Through Housing Solutions, REPORT ON MAKING THE CONNECTION...HOUSING AND WORKFORCE DEVELOPMENT: A NATIONAL LEADERSHIP FORUM (2006), available at http://www.jchs.harvard.edu/publications/markets/wh05-1_workforce_housing_report.pdf; Carol A. Bell, Workforce Housing: The New Economic Imperative?, 4(2) FANNIE MAE HOUSING FACTS \& FINDINGS, available at http://www.fanniemaefoundation.org/programs/hff/v4i2workforce.shtml.

${ }^{47}$ Contemporary non-profit affordable housing is largely indistinguishable from market-rate housing. See, e.g., GoOD NeIGHBORS: THE DESIGN OF AFFORDABLE FAMILY HOUSING (Pyatok, Jones \& Pettus eds., 1995). However, this similarity renders it relatively invisible to the public. Ironically, due to its relative invisibility, the newer versions of affordable housing have a limited capacity to replace the past images that continue to occupy the public's imagination.
} 
for their achievements. This kind of positive, sustained and careful attention to affordable housing due to the PPP form may demonstrate how appropriatelydesigned and professionally-managed affordable housing is an asset to a community and address affordable housing's public relations problem. ${ }^{48}$

An exciting and even historic opportunity presented by the PPP model is its potential to reposition affordable housing in American housing policy and law. ${ }^{49}$ Currently "affordable housing" is ideologically framed as special pleading for individual "welfare rights" for unpopular populations and/or as a government redistribution program. ${ }^{50}$ Perhaps PPPs of affordable housing can reposition affordable housing as promoting a public interest in pragmatic community development. ${ }^{51}$ By emphasizing the important public and private interests served in affordable housing production (further discussed below), a greater focus on affordable housing development as PPP could serve an important educative function to numerous important audiences, including local elected officials and policymakers, the media, and the general public.

\footnotetext{
48 See The Campaign for Affordable Housing, "The Campaign for Affordable Housing is a national, nonpolitical nonprofit organization dedicated to dispelling the negative stereotypes surrounding affordable housing. ...The Campaign is solely dedicated to the message that affordable housing is an asset to our communities and that citizens who understand its value must take action to support its creation." See The Campaign for Affordable Housing, About Us: About the Campaign, http://www.tcah.org/about_us.cfm (last visited May 5, 2008).

49 To a large extent, the fulfillment of this opportunity would be the cumulative effect of success in each of the previously described opportunities. Another historic opportunity posed by PPPs is their potential for reforming and revitalizing governance structures, but that topic is beyond the scope of this chapter.

${ }^{50}$ See supra note 44.

51 The more recent emphasis by affordable housing movement on the Housing as One Land Use in a Functional System ethic also helps counter this tendency. See discussion, infra at notes 62 - 69 and accompanying text.
} 
In particular, a broad functional approach to PPPs raises the potential for more constructive conversations and debates about the relative roles of government, the private for-profit sector, the non-profit sector, and even more broadly, civil society in responding to our chronic housing crisis. ${ }^{52}$ By its own terms a PPP in affordable housing development points beyond neoclassical economics' facile assumption of a "pure public" sector and a "pure private" sector which underlies some critiques of government involvement in the housing sector. Lamenting the misunderstanding of PPPs in the redevelopment context by the United States Supreme Court in the Kelo case ${ }^{53}$ Professor Marc Mihaly notes that public and private roles are no longer separate but are commingled. ${ }^{54}$ This failure to understand is "poignant because much of this entire sea change in land use comes at the urging of thoughtful conservatives who have spearheaded, intellectually and in practice, the movement to remake government in ways that imitate qualities found in the private sector, and to bring to government land-use planning an understanding of economies and the operation of markets." ${ }^{, 55}$

As more legal and policy analysts and other opinion-leaders come to understand how PPPs work and to appreciate the breadth of possibilities in

\footnotetext{
${ }^{52}$ This analysis assumes that the vexed question of whether the lack of affordable housing is caused by overregulation of the market or by market failures is not irresolvable, and that in the pragmatic structuring of PPPs to produce affordable housing this sometimes ideological conflict can be finessed or avoided.

${ }^{53}$ Kelo v. City of New London, 545 U.S. 469 (2005).

${ }^{54}$ Mihaly, Public-Private Redevelopment Partnerships, supra note 27, at 42 (“... [T] he very nature of land development in the city center has evolved, altering both public and private roles, erasing traditional boundaries between what is a public use and what is a private use, and between what is government owned and what is privately owned.").

${ }^{55} I d$. at 61.
} 
affordable housing development through various kinds of PPPs, the policy environment for affordable housing could improve. The formation, funding and operation of PPPs in affordable housing require the parties to construct a collaboration across sectors in which parties play different roles but work together to develop and operate affordable housing. The process of defining, negotiating, publicly explaining and implementing affordable housing development through PPPs may undercut the old categories and spur more sophisticated insight into relationships between the public sector, the market and other elements of civil society. For their part, experienced non-profit developers of affordable housing have learned the importance of market principles and considerations. And, the collaboration of some for-profit developers with their non-profit counterparts has engendered mutual respect. Acknowledging together that the successful development of affordable housing that truly serves community needs over the long term is a complex enterprise which PPP collaboration can enhance could help policy debates move beyond simplistic "government" versus "market" categories. This overdrawn distinction is impossible to sustain in the actual practice of PPPs.

The public values achieved by government promotion of homeownership have been consistently and widely recognized. ${ }^{56}$ Deeper engagement with PPP

\footnotetext{
56 The typical public benefits cited as a result of homeownership include "good citizens, stable neighborhoods and strong communities." William M. Rohe, Shannon Van Zandt \& George McCarthy, The Social Benefits and Costs of Homeownership: A Critical Assessment of the Research 3 (Joint Center for Housing Studies of Harvard University, Low-Income Homeownership Working Paper Series LIHO-01.12, October 2001), available at http://www. jchs.harvard.edu/publications/homeownership/liho01-12.pdf. See generally D. Benjamin Barros, Home as a Legal Concept, 46 SANTA ClARA L. ReV. 255 (2006). Some commentators, however, have argued that the dominant focus on homeownership amounts to an unjustified bias against rental form of tenure. Nicolas P. Retsinas \& William Apgar, Opinion: Homeownership Should Not
} 
development of affordable housing and further research might similarly reveal and affirm the public goals served by all housing, and specifically affordable housing. ${ }^{57}$ The PPP discussion might make the longstanding and important public/governmental roles and interest in all housing development both more explicit and better understood. ${ }^{58}$ Depending upon how broadly one defines "public" and "private" roles, arguably nearly all housing development in America is PPP; affordable housing is just more explicitly so. For example, the federal government played a crucial role in the creation of both the 30 year mortgage and

be Sole Barometer of Housing Success, MASSACHUSETTS HOUSING PARTNERSHIP NEWS, July 15 , 2005, available at http://www.mhp.net/homeownership/news.php?page_function =detail\&mhp_news_id=22.

57 For example, see Dryer and Diamond, Matrix Revealed, supra note 8 (articulating social goals served by affordable housing and calling for more research). The argument is that while affordable housing is not a "public good" in the technical economic sense of the term, it at least has certain significant positive externalities that ground a public interest in ensuring its development and preservation. In Home Builders Association of Northern California v. City of Napa, a California Court of Appeal recognized the social value of affordable housing when it upheld an inclusionary zoning ordinance against a facial regulatory takings claim. Home Builders Association of Northern California v. City of Napa, 90 Cal. App. $4^{\text {th }} 188$ ( $1^{\text {st }}$ Dist. 2001), cert. denied, 535 U.S. 954 (March 25, 2002). The court wrote:

City, like many other localities in California, has a shortage of affordable housing. This shortage has negative consequences for all of City's population, but causes particularly severe problems for those on the lower end of the economic spectrum. Manual laborers, some of whom work in the region's wine or leisure industries, are forced to live in crowded, substandard housing. There is a large and growing population of homeless, including many families and teenagers. Workers from low-income families increasingly are forced to live greater distances from their places of employment, which causes increased traffic congestion and pollution.

Id. at 191 .

${ }^{58}$ Consistent with this, Steinberg explains how housing is not just a private good and articulates five ways in which housing is different from many other goods: (1) society's interest in providing "a minimum standard of occupancy for all," not equality of outcomes; (2) "housing is rife with externalities," e.g., NIMBY; (3) the "long lags in supply adjustments"; (4) the "ownership/rental choice in housing"; and, (5) "housing policy is used to regulate the overall economy." Richard Steinberg, The Theory of the Nonprofit Sector in Housing, in SHELTER AND SOCIETY: THEORY, RESEARCH, AND PoliCy FOR NonPROFIT Housing 35 (C. Theodore Koebel ed., 1998). See also Robin Paul Malloy, Inclusion by Design: Accessible Housing and the Mobility Impaired , 60 HASTINGS L.J. __(March 2009). 
the secondary mortgage markets. ${ }^{59}$ Affordable housing advocates have long argued that the federal mortgage interest deduction (America's largest "housing program" measured by dollars) ought to be considered a housing subsidy. ${ }^{60}$ And, some courts have held that the development of affordable housing is a "public purpose. ${ }^{\prime 61}$ Recognition of the public role in all housing development could blunt the force of arguments characterizing affordable housing as merely another welfare program for underprivileged (and possibly unworthy) populations. Then with affordable housing repositioned in this way, public involvement in affordable housing development will appear as normal and uncontroversial as our government's commitment to homeownership.

\footnotetext{
${ }^{59}$ Federal government action made 30 year mortgages possible which in turn significantly expanded the market for home purchases and also created the government enterprises Fannie Mae and Freddie Mac (now quasi-public) which formed the secondary market for mortgages that significantly expanded access to homeownership and created new, lucrative housing investment opportunities. See Kent W. Colton, Housing Finance in the United States: The Transformation of the U.S. Housing Finance System, JoINT CENTER FOR Housing STUDIES AT HARVARD UNIVERSITY (2002), available at http://www.jchs.harvard.edu/publications/finance/W025_Colton.pdf.

${ }^{60}$ Chester Hartman, The Case for a Right to Housing, 9 HousING POL'Y DEBATE 223, 235 (1998) ("The various homeowners' income tax deductions provide the federal government's only true (civilian) housing entitlement 'program': All homeowners are entitled to deduct from their taxable income base virtually all mortgage interest and all property taxes...") See Peter Drier, The New Politics of Housing, 63 J. OF THE AMERICAN PLANNIng AssoCIATION 5, 9 (1997) ("The federal tax code allows all homeowners to deduct mortgage interest payments from their income taxes. Whether it is labeled a 'subsidy' or a 'tax expenditure,' the homeowner deduction cost the federal government over $\$ 53.3$ billion in 1995 alone.") Of course, defenders argue that the tax deduction is not a "subsidy." Some argue that although it is only a statutory policy, it should be considered as a "right" because it is treated as politically inviolable entitlement.

${ }^{61}$ Utah Housing Finance Agency v. Smart, 561 P.2d 1052 (1977) (upholding state legislation establishing state housing finance agencies from state constitutional claims recreating public debt, lending state credit, and using public funds for private activities). "The legislature therefore specifically declares it a public purpose for the State to cooperate with private institutions to increase the amount of reasonably available financing for the construction, purchase, and rehabilitation of decent, low and moderate income housing." Id. at 1053. And, see Home Builders Association of Northern California v. City of Napa I, supra note 57.
} 
For the affordable housing movement to take full advantage of this

opportunity to reposition affordable housing in American housing law and policy, these understandings of PPP could be combined with a de-emphasis on the Housing as a Human Right ethic and a greater emphasis on the Housing as One Land Use in a Functional System ethic. This housing ethic is particularly compatible with the PPP development model. And it draws attention away from individual "welfare" rights to housing toward what might be called "social rights to housing opportunities." ${ }^{, 62}$ This ethic can help neutralize affordability’s historical association with divisive poverty and race issues. Certain versions of this ethic challenge (implicitly at least) stereotypes about what kind of people need and qualify for affordable housing, highlighting that workers in "good jobs" also both need and qualify for it. ${ }^{63}$

To some extent, the affordable housing movement has engaged in this shift in the last twenty years. This change is evidenced in the recent focus on "workforce housing," inclusionary zoning ordinances, commercial linkage fee programs, and mandatory "housing elements" as part of comprehensive plans, all of which present affordable housing as one necessary land use for a workable community

\footnotetext{
${ }^{62}$ This point does not diminish the fact that the affordable housing movement's historical reliance on the Housing as a Human Right ethic has generated critically important individual housing rights and policies. Yet, in the view of the author, this ethic is unlikely to be as useful in the foreseeable future due to courts' reluctance to interpret law expansively to recognize individual housing rights and legislatures' reluctance to expand what are perceived as "welfare rights" for individuals. It should also be noted that there are strong and enduring tensions between affordability and some environmentalist versions of the "housing as one land use in a functional system" ethic. And, it is uncertain whether this ethic can support affordability for very low income households, including homeless people.

${ }^{63}$ Of course, the struggle about affordability is: how far does the "workforce" definition go? Does it include low-wage workers in hotels, restaurants, and private homes who are needed for a city to work?
} 
rather than as a human right. These policies can be understood as "developmental policy" for cities, rather than as "redistributive policy" as many past housing programs are perceived. ${ }^{64}$ This helps to extricate affordability from its excessive entanglement with stereotypes associated with poverty and race. ${ }^{65}$ In addition, each of these policies can be fairly characterized as examples of "social rights to housing opportunities.” In a social right to housing, government owes a legal obligation to the community, and the law provides a private right of action against the government to ensure fulfillment of that duty. ${ }^{66}$ However, a successful plaintiff's relief is not an individual claim to a housing unit, but rather an injunction requiring the city to follow the law requiring it to take actions which will benefit the community. ${ }^{67}$ State legislatures and city governments are more likely to enact social rights to affordable housing because they do not commit

${ }^{64}$ See Victoria Basolo, Explaining the Support for Homeownership Policy in US Cities: A Political Economy Perspective, 22 HousING STUDIES 99 (2007) (making a similar distinction about local government policies favoring homeownership). Of course, developers and landowners may still perceive and oppose such policies as redistributive.

${ }^{65}$ This is not to deny the historical fact that many policies harming affordability were embraced and broadly accepted because alternative policies would largely benefit members of a disfavored race or class. Nor is it to deny that the statistical correlation between race, poverty and that the need for affordable housing is, in part, an effect of such previous policies. The point here is to argue that currently negative stereotypes continue to plague affordable housing policies and proposed developments when in the current situation affordability problems extend well beyond those communities.

${ }^{66}$ Professor Bo Bengtsson addresses a similar concept regarding Swedish housing law in Bo Bengtsson, Housing as a Social Right: Implications for Welfare State Theory, 24(4) SCANDINAVIAN POLITICAL STUDIES 255 - 275 (2001) (copy on file with author).

${ }^{67}$ The term "social right to housing" should be distinguished from the common expression "social housing" which refers to either government-supplied or government-subsidized housing, especially in Europe. 
themselves to large open-ended financial commitments. ${ }^{68}$ Courts are more comfortable enforcing these rights because this exertion of judicial power seems more consistent with separation of powers doctrines - to the degree they are mandating expenditures, they are only expenditures that the government has already committed itself to. ${ }^{69}$ The resulting housing rights would be a patchwork, but that is only realistic given our housing ethics pluralism.

A crucial benefit of such repositioning of affordable housing in American law and policy could be stability in affordable housing policy, such as that enjoyed by homeownership policies. ${ }^{70}$ A policy or law is most stable when supported by several housing ethics. Affordability can be consistent with some version of each of the housing ethics. Greater attention to affordable housing development as PPP could help move in that direction. Affordability is consistent with versions of the "housing as an economic good" ethic, including those that emerge from pragmatic collaborations between the public sector, the market and civil society expressed in affordable housing PPPs. Increasing the number, type and visibility of such

\footnotetext{
${ }^{68}$ While the size of a state's financial commitment for mandating local government planning that includes planning for affordable housing is not insubstantial, it is small relative to funding the subsidies required for meeting housing needs founded upon individual housing rights.

${ }^{69}$ To be effective, of course, the "social rights to housing opportunities" strategy must include broad legal standing for complainants and sufficient legal resources to enforce such rights. An administrative complaint option would also be useful. See Ben Field, Why Our Fair Share Housing Laws Fail, 34 SANTA Clara L. REV. 35, 50-51 (1993); Brian Augusta, Comment, Building Housing from the Ground Up: Strengthening California Law to Ensure Adequate Locations for Affordable Housing, 39 SANTA CLARA L. REV. 503, 513-14 (1999). Attorney's fees awards to parties prevailing over a government defendant would also be appropriate and useful. See, e.g., Mike Geniella, Ruling Favors Housing Lawsuit: Mendocino County Must Pay \$70,000 in Legal Fees, SANTA ROSA PRESS DEMOCRAT, Sept. 28, 2005 (reporting attorneys fees award for successful lawsuit under California's housing element law).

${ }^{70}$ For a discussion of the stability of U.S. housing policies promoting homeownership see supra note 17.
} 
collaborations and the consequent broader participation of the private sector in creating affordable housing opportunities more deeply anchors affordability in the "housing as an economic good" ethic because of the participation of the private sector itself. The "housing as home" ethic is largely indifferent to affordability, but nothing in this ethic would deny someone a home because of her income. This ethic could be mustered to support affordable housing PPPs that expand opportunities for families to experience the benefits of "home," whether as homeowners or renters. ${ }^{71}$ Of course, the Housing as a Human Right (affordability's natural "home" ethic) can support any policy that provides housing to those in need as PPPs certainly do. Our established "housing as part of social order" ethic is largely hostile to affordability, but competing inclusive visions of community could promote affordable housing as integral to a healthy community. PPP affordable housing development can foster these inclusive visions because the public spectacle of government, private for-profit business, and other segments of civil society working together to create affordable housing legitimates the resulting community and its diverse membership. Finally, "housing as one land use in a functional system" ethic supports affordability when it is seen as functionally necessary and as an asset to the community. Extended commitments of time, money and organizational resources by businesses, chambers of commerce, and a wide range of other collaborators to produce affordable housing in a PPP can testify to its necessity and value for a community.

${ }^{71}$ See, e.g., Megan J. Ballard, Legal Protections for Home Dwellers: Caulking the Cracks to Preserve Occupancy, 56 SYRACUSE L. REV. 277, 277 (2006) (employing "housing as home ethic" arguments to promote adoption of new housing rights for tenants). 
As is frequently the case, the risks are in some substantial measure the flipside of the opportunities. The primary risk associated with potential expansion of subsidies for affordable housing development through PPPs is their possible contraction. PPPs in affordable housing development could become a victim of their own success. This could happen, for example, if Congress perceived the amount of resources from state and local governments and private sources dedicated to affordable housing PPPs as justifying a further reduction in federal commitments. The affordable housing movement could address this risk by continuing to educate the public, decision-makers and the media about the success of PPPs, the continuing need for affordable housing, and the continuing need for a strong federal government role.

The other side of the fact that PPPs create synergistic wholes that are "greater than the sum of their parts" ${ }^{, 72}$ is that PPPs raise complex efficiency, public accountability and contracting issues. ${ }^{73}$ Developers need to be open to continued multiplicity of production methods and strategies using PPPs' potential for fractionalizing property rights. However, with any substantial experimentation comes failure. Some PPPs will fail, and some will fail miserably and, possibly, in a very public manner. ${ }^{74}$ If affordable housing PPPs are widely perceived as inefficient, ineffective, or unaccountable, then the attempt to reposition affordable

\footnotetext{
${ }^{72}$ See supra note 39.

${ }^{73}$ See Davidson, Relational Contracts, supra note 2.

${ }^{74}$ Connie Susilawati \& Lynne Armitage, Do Public Private Partnerships Facilitate Affordable Housing Outcome in Queensland?, 2004 AUSTRALIAN PROPERTY JOURNAL 184 (2004) (Proceedings 11th European Real Estate Society Conference, Milan, Italy) (finding that the program failed to produce any affordable housing units because of inappropriate design).
} 
housing through them will fail; and the hope of changing negative public perceptions of affordable housing will be disappointed and may even backfire. ${ }^{75}$

To guard against this risk, the affordable housing movement should strive to make affordable housing PPPs as efficient and politically accountable as possible, given the public goals. ${ }^{76}$ For example, the Corporation for Supportive Housing has addressed this issue head-on with several evaluative studies demonstrating supportive housing's relative economic efficiency to other housing and treatment options for homeless people. ${ }^{77}$ There are signs that the leadership of the affordable housing movement is concerned about this problem. ${ }^{78}$ And, national intermediaries supporting affordable housing development, such as the Local

\footnotetext{
${ }^{75}$ For example, the LIHTC program would be a politically vulnerable type of PPP. Ironically, the LIHTC program, which was heralded as a market-oriented reform to our national housing policy, is probably the least efficient means of subsidizing housing because of its high transaction costs. See, e.g., Sagit Leviner, Affordable Housing and the Role of the Low Income Housing Tax Credit Program: A Contemporary Assessment, 57 TAX LAW. 869, 878 - 881 (2004). However, despite the fact of its well-documented economic inefficiency, the LIHTC program consistently garners broad and powerful political support. This result may be explained by the fact that those transaction costs represent income for lawyers, bankers, and accountants, all traditionally politically powerful groups.

${ }^{76}$ Professor Davidson's article, Relational Contracts, supra note 2, addresses the inherent difficulty in this task.

77 See Corporation for Supportive Housing (CSH), Research and Evaluation: Using Evidence to Advance Systems Page, http://www.csh.org/index.cfm?fuseaction=page.viewPage\&pageID=3749\&nodeID=81 (last visited May 6, 2008).

${ }^{78}$ In the "Chair's Message" introducing the Spring 2000 issue of the Journal of Affordable Housing and Community Development Law, Angela Christy expresses concerns about the lack of cooperation and coordination among a multitude of players in affordable housing transactions, that deals are unnecessarily complex and expensive, growing conflicts between developers and governmental entities (e.g., regarding supportive housing), and an adversarial approach between HUD and private partners leading to increased litigation. She then calls for needed reforms. And, she offers Interagency Stabilization Group that the Twin Cities created as an example of good collaboration.
} 


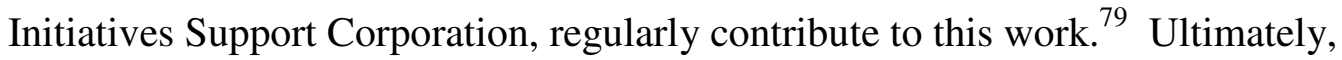
this may require developing a more sophisticated definition and analysis of "efficiency" that accounts for what might be called the "double-bottom line" of these programs serving both private and public goals. ${ }^{80}$

Just as affordable housing PPPs open up the potential for broader and deeper conversations about the relative roles of government and the market in affordable housing production, the dialogue could get caught up in "market fundamentalism" - the view that a priori always and everywhere markets are better than government. ${ }^{81}$ Some free-market promoters want to use PPP as a means/rhetorical device to criticize government, e.g., PPP as merely a form of privatization. ${ }^{82}$ This definition of PPPs limits their goals to "private" ones,

${ }^{79}$ See, e.g., Local Initiatives Support Corporation (LISC), Organizational and Professional Development Programs, http://www.lisc.org/section/areas/sec5 (last visited January 12, 2008). U.S. Department of Housing and Urban Development, Building Public-private Partnerships to Develop Affordable Housing, 1583 HUD COMMUNITY PLANNING AND DEVELOPMENT (May 1996), available at http://www.ezrc.hud.gov/offices/cpd/affordablehousing/ library/modelguides/1583.cfm. Working under HUD contract, four national technical assistance providers-The Enterprise Foundation, The National Development Council, The Local Initiatives Support Corporation and The Community Builders-worked to create "local affordable housing partnerships, supporting strategic planning for affordable housing, increasing the production and availability of suitable, affordable housing and improving the capacity of community-based development organizations (CHDOs) to develop affordable housing and participate in local partnerships." Id.

${ }^{80}$ See Byrne and Diamond, Matrix Revealed, supra note 8 at 612 (calling for more research and analysis concerning the "efficiency" of affordable housing programs); and see Davidson, Relational Contracting, supra note 2.

${ }^{81}$ See, e.g., Fred Block, Reframing the Political Battle: Market Fundamentalism vs. Moral Economy, http://www.longviewinstitute.org/projects/moral/sorcerersapprentice (last visited January 12, 2008).

${ }^{82}$ In defining "privatization" E.S. Savas, a prominent privatization advocate, writes: 'The term 'public-private partnership' is particularly malleable as a form of privatization. It is defined broadly as an arrangement in which a government and a private entity, forprofit or non-profit, jointly perform or undertake a traditionally public activity....Despite its ambiguity, 'public-private partnership' is sometimes a useful phrase because it avoids the inflammatory rhetoric of 'privatization' on those ideologically opposed." 
excluding public values and goals served by PPPs. It makes affordable housing PPPs a part of a wholesale privatization policy rather than an alternative to wholesale deregulation. This chapter articulated the counter argument. To manage this risk, the affordable housing movement must engage vigorously in the public conversation defining the meaning and purpose of PPPs to include achieving both private and public goals. At the same time, the affordable housing movement must be open to deregulation where it makes sense, e.g., in reducing zoning and planning restrictions imposed by local governments on market-affordable housing types (e.g., manufactured housing and secondary units). ${ }^{83}$

Finally, there is another risk overshadowing any optimistic scenario. In order for the affordable housing movement to take advantage of these opportunities, there will need to be some substantial unity in its response to them. PPPs in affordable housing development challenge affordable housing advocates to agree on what it is they are seeking in PPPs, but as discussed above, the term "PPP" is ambiguous. Affordable housing development through PPPs poses many difficult issues to the diverse and sometimes divided affordable housing movement. ${ }^{84}$ What definition(s) of "public-private partnership" should it advocate? What

E.S. SAVAS, PRIVATIZATION AND PUBliC-PRIVATE PARTNERShIPS, http://www.cesmadrid.es/documentos/Sem200601_MD02_IN.pdf (last visited May 5, 2008).

${ }^{83}$ See Tim Iglesias, State and Local Regulation of Particular Types of Affordable Housing, in THE Legal Guide to AFFORDABLE Housing DeVElopMent (Tim Iglesias \& Rochelle Lento eds., American Bar Association 2005).

84 “'Public-Private Partnerships' has become a popular buzzword over the past two decades. Whether they are successful, who pays, and who benefits have been the subject of considerable debate." W. Dennis Keating, Encouraging Middle-Class Homeownership in NYC, SHELTERFORCE MAGAZINE, July/August 1998 Reviews (book review of CHARLES J. ORLEBECKE, NEW LIFE AT GROUND ZERO: NEW YORK, HOMEOWNERSHIP, AND THE FUTURE OF AMERICAN CitIES (The Rockefeller Institute Press 1997)). 
public goals for PPP collaborations should it pursue and with what partners?

Which regulatory strategies and subsidy programs should it promote? ${ }^{85}$ What types of developments (homeownership or rental, mixed use or single use, mixed income or $100 \%$ affordable) should be prioritized? What should be the role of the local community in which a new development will be sited?

Overall, in the author's estimation, the potential opportunities offered by PPPs for affordable housing development make the risks worth taking. To date, the affordable housing movement has proven relatively adept at conceiving, initiating and implementing PPPs. While some advocates are skeptical of PPPs (or at least specific PPPs), ${ }^{86}$ many have embraced them. ${ }^{87}$ The challenge will be to identify through practice which PPPs most effectively promote affordable housing and

\footnotetext{
${ }^{85}$ One particularly intriguing possibility is whether affordable housing produced pursuant to inclusionary zoning ordinances which include regulatory relief and/or subsidy can be appropriately characterized as "public-private partnerships." The author will address this possibility in future scholarship. Inclusionary zoning ordinances are typically enacted by local governments. For more information, see Inclusionary Zoning: The California Experience, 3(1) NHC AFFORDABle Housing Policy Review (National Housing Conference, Washington, D.C.), February 2004, available at http://www.nhc.org/pdf/pub_ahp_02_04.pdf.

${ }^{86}$ Mitch Kahn, Paradise Lost, 138 Shelterforce Magazine, November/December 2004 (book review of J.S. Fuerst, WHEN PUBLIC HOUSING WAS PARADISE: BuILDING COMMUNITY IN CHICAGO (University of Illinois Press 2004)) (arguing that when PPPs work they do so because they are following the same policies that a properly run government housing would); "Housing advocates have long questioned the efficacy of paying for-profit developers to operate low-income housing [under the federal Section 8 program]...." Rachel G. Bratt, A Withering Commitment, SHELTERFORCE MAGAZINE, July/August 1997; Norman Krumholz, The Reluctant Hand: Privatization of Public Housing in the U.S. (criticizing the HOPE VI program), http://www.uic.edu/cuppa/cityfutures/papers/ webpapers/cityfuturespapers/session1_4/1_4reluctanthand.pdf (last visited January 12, 2008); Letters, The Myth of the Double Bottom Line, 127 SHELTERFORCE MAGAZINE, January/February 2003, available at http://www. nhi.org/online/issues/127/letters.html. See also criticisms of the LIHTC program, including for its inefficient use of public funds, supra note 75.

87 "The consistent leadership of local elected officials in support of public/private partnerships and system building make Santa Fe a model for other cities trying to respond to seemingly intractable housing needs." Peter Werwath, Words into Action: A New Housing Delivery System for Santa Fe, SHELTERFORCE MAGAZINE, March/April 1996, available at http://www.nhi.org/pdf/EnterpriseRelease1106.pdf.
} 
then to unite around advocating for those forms ${ }^{88}$ while maintaining the

historically favored form of PPPs in affordable housing development--direct government subsidies.

88 Drawing on the lessons of these cases, and from previous research, [the National Housing Institute] outlines steps the federal government can and should take to create effective partnerships with state and local governments and the thousands of community-based organizations (CBOs) dedicated to saving affordable housing and rebuilding the communities in which low- and moderate-income Americans live. By studying these successful partnerships, NHI aims to help guide future efforts to save affordable housing."

National Housing Institute, Shelterforce Online, Saving Affordable Housing: Introduction, http://www.nhi.org/ online/issues/90/intro.html (last visited January 12, 2008). 